\title{
TRANSLATION ANALYSIS OF CIRCUMSTANCES IN THE GOSPEL OF MATTHEW CHAPTER 12 THROUGH 14 FROM ENGLISH INTO INDONESIAN
}

\author{
Burwan Tilusubya $^{1}$; Mangatur Nababan²; Riyadi Santosa ${ }^{3}$ \\ 1,2,3 Department of Linguistics, Graduate Studies, Sebelas Maret University \\ Jl. Ir. Sutami No. 36-A, Kentingan, Surakarta 57126, Indonesia \\ 'btilusubya@gmail.com; ${ }^{2}$ Amantaradja@yahoo.com; ${ }^{3}$ riyadisantosa@staff.uns.ac.id
}

Received: $13^{\text {th }}$ April 2018 /Revised: $12^{\text {th }}$ September $2018 /$ Accepted: $25^{\text {th }}$ September 2018

\begin{abstract}
How to Cite: Tilusubya, B., Nababan, M., \& Santosa, R. (2018). Translation analysis of circumstances in the Gospel of Matthew chapter 12 through 14 from English into Indonesian. Lingua Cultura, 12(4), 415-421.

https://doi.org/10.21512/lc.v12i4.4608
\end{abstract}

\begin{abstract}
This research deployed translation of circumstances, viewed from transitivity with the descriptive qualitative method. Its objectives were to describe the translation technique of the circumstances and to evaluate the quality of the translation based on accuracy and acceptability. It utilized document analysis and focus group discussion for data collection. The data were analyzed through the domain, taxonomy, componential analysis, and finding cultural value. Meanwhile, the research indicates the application of established equivalent, combination, modulation, transposition, paraphrasing, deletion, explicitation, discursive creation, and implicitation techniques are influenced by the form of a circumstance or an adverb. Furthermore, the application of established equivalent, combination, and implicitation produces a good translation based on accuracy compared to modulation, transposition, explicitation, and paraphrasing. The research concludes that the deployment of appropriate translation techniques produces a good translation.
\end{abstract}

Keywords: circumstance, translation quality, translation technique

\section{INTRODUCTION}

In today's globalized world, people keep searching for information because they believe information is power. People want to know what is happening in the neighborhood either politically, economically, socially, and/or religiously. Unfortunately, differences in languages and culture from one social community to another have created a gap in which the sharing of information in a smooth way that has become a problem. This problem has created the need for scholars in the linguistic field of translation to translate different materials into different accessible languages of the world, so as to bridge the gap that is caused by these language and cultural differences.

Linguists claim that the sole purpose of any translation work is the transfer of the message from the Source Text (ST) into the Target Text (TT) in a simple manner that the reader of the TT will experience the same experience as the reader of the ST that have experienced at reading the ST (House, 2015; Supatmiwati, 2013). In so doing, examining the meaning of a literary text (ST) by applying an appropriate theoretical tool before translating it can be a means to full understanding. This is because what may be thought difficult to understand is put open (Leech
\& Short, 2007). To achieve this purpose scholars in the field of translation have carried out a number of researches utilizing transitivity analysis which is part of the ideational metafunction of language (experiential meaning) as a tool to unfold the meaning of each clause within the text. As a tool, transitivity unlocks the text by describing the experience as a kind of process that is associated with the participants and circumstances at a clause level (Halliday, 2014). For instance in the clause, "At that time, Herod the tetrarch heard about the fame of Jesus" (Bible Society of South Africa, 1971). At that time [Cir: Loc. Time] Herod the tetrarch [Part: Senser] heard [Pro: Mental] about the fame of Jesus [Phenomenon].

Previous research on translation studies that have utilized transitivity has paid much focus on processes while doing little on circumstances within the clause. One of these concludes that mental processes are used to portray the character as a thoughtful being before taking any action to avoid making avoidable mistakes. This finding agrees together with another research that compares the processes used in Malaysian and Singaporean language. In this research, researchers want to find out how different processes in the two language community studied are used to unlock the experiences in its social context. It is found out that verbal processes are used to show power in Malaysian 
while existential processes are used to show agency in Singaporean. They further add that behavioral processes in both languages are given less emphasis (Idrus, Nor, \& Ismail, 2014; Zahoor \& Janjua, 2016).

Other research concludes that material process dominated in both the source text and target text, while relational processes rank the second (Behnam \& Zamanian, 2015; Beji, 2016; Manggala, 2017; Nguyen, 2012; Wang, 2010). Deploying descriptive qualitative method, they add that diligence is fully supported by the material process, obedience by material, verbal, mental, relational, and behavioral are used to show kindness. Apart from that, the research on the two language culture between English and Chinese concludes that the six processes within transitivity are semantically the same in both languages (Sun \& Zhao, 2012). This corresponds to another research on relational attributive clauses in narrative texts between English and Persian through transitivity, which indicates that different attributive processes in the attributive relational clauses are used in both the source text and the target text (Kaffashi et al., 2015).

Furthermore, the research by Chen (2014); Sabbachat, Mahdi, and Sumantri (2014) conclude that the circumstantial part of a clause is not the focus of their research, but processes to reveal that some characters are portrayed involving in some processes and not the others. Therefore, the circumstantial part of transitivity based on translation studies is the gap and the focus of this research specifically from The Gospel According to Matthew chapters 12,13, and 14 as the source text and its Indonesian version as the target text.

Basically, the purpose of this research is to describe and explain the translation techniques of the circumstances found in the target text in relation to the source text and to evaluate the quality of the translation based on the aspects of accuracy and acceptability (Molina \& Albir, 2002; Nababan, Nuraeni, \& Sumardiono, 2012). The research also intends to answer the questions what type of translation techniques are deployed by the translator and the reason why its deployment in the target text. In so doing, the research provides complete information about the type of translation techniques used in the target text to those who find interests in the field of translation. It is practically expected to trigger debates and discussion amongst scholars in the field of linguistic translation either by critically supporting or criticizing the results and the suggestions that are arrived at regarding the translation of circumstances.

The linguist, Halliday (2014), claims that circumstances are names of those elements within the clause which carry semantic role but are neither processes or participants. It is one of the three elements of transitivity which is said to occur freely within the clause and more peripheral than the participant. These describe how the process is carried out and are dominated by adjuncts or prepositional phrases. Halliday (2014) categorizes these elements into nine types in accordance to their functions, namely: (1) location, (2) extent, (3) manner, (4) cause, (5) accompaniment, (6) angle, (7) contingency, (8) role, and (9) matter. For example, in the clause "But the Pharisees went out...", the word 'out' functions as a circumstance of location showing where the destination of the movement is being directed.

On the contrary to circumstances, as pioneered by Halliday, translation techniques are said to be procedures deployed by the translator to analyse and classify the equivalence or closeness of the translation in relation to the source text. Linguists, Molina and Albir (2002), provide detailed clarification on the revised 18 translation techniques. Some of those techniques are Established Equivalence, Reduction, Linguistic Amplification, Transposition, Borrowing, and Discursive Creation. For example, in chapter 12 verse 28 the author writes:

\section{ST: "But it is by the spirit of God that I cast out demons..." \\ TT: “Tetapi Aku mengusir roh jahat dengan kuasa Roh Allah..."}

From the example in chapter 12 verse 28, Established Equivalent in combination with Explicitation techniques are applied by the translator on the ST phrase, “...by the Spirit of God..." to have the TT phrase "...dengan kuasa Roh Allah...". Explicitation comes into target text because of the word "...kuasa..." which means that the translator clarifies to the reader that the power referred to is that which comes from God.

The final purpose of any translation process is to obtain the text that precisely renders the message as close as in the source text. In this case, equivalence becomes the fundamental criterion of translation quality because the target text has a function that is equivalent to that of the source text. For any translation to be valued quality (Nababan, Nuraeni, \& Sumardiono, 2012), it has to conform to three aspects that are used as tools of assessment, namely: (1) accuracy is checking whether the source text message that is precisely rendered in the target text. (2) Acceptability is conforming the naturality of the target text in terms of grammar, rules, and the cultural aspects of that language structure. (3) Readability is checking and ensuring whether the meaning of the target text can be understood (House, 2015; Nababan, Nuraeni, \& Sumardiono, 2012). This research utilizes only the two aspects of accuracy and acceptability as it is dealing with just some elements within the text and not text as a whole.

\section{METHODS}

The research employs a descriptive qualitative method because it is driven by the desire of the researcher to describe the behaviour or the phenomenon and its occurrence based on the objectives of the research (Santosa, 2017). It utilizes transitivity analysis as a tool to unlock the circumstantial elements within the selected text. In Halliday's transitivity, the clause is classified into three categories of process, participant, and circumstance (Halliday, 2014). Thus, transitivity is applied to determine whether a certain structure within the text studied is a circumstance or not.

The problems investigated are the translation techniques and its translation quality of the identified circumstantial elements from the text. The research utilizes both primary and secondary data. Primary data includes linguistic and its translational data in forms of a word or phrase structures standing for circumstantial elements within the clauses that are extracted from chapters 12 , 13, and 14 of the text of Matthew, and its translational data in forms of translation techniques in relation to its translation quality. On the contrary, secondary data are all related information (additional) and previous research that supports this research. The data are purposely sampled and then collected through document analysis and focus group discussion techniques. The sampled data are only 
those clauses that contain circumstantial elements within the text. The data are extracted from the rest of the text after a thorough and intensive reading and then recorded on the separate sheet. On the other hand, the focus group discussion involves three professionals in the field of translation and the researcher himself. This activity is done in February 2018. The gathered data are then analyzed through the domain, taxonomy, componential analysis, and then the researcher determines its cultural value to arrive at a conclusion (Spradley in Santosa, 2017).

\section{RESULTS AND DISCUSSIONS}

Based on the analysis of the studied texts, there are a total number of 144 data as circumstances. These are the circumstances of location that consist of circumstances of location 97 data, manner 25 data, cause 8 data, accompaniment 9 data, and circumstances of extent 5 data. However, there are observable changes that appear in the target text as can be seen in Table 1.

Table 1 Distribution of Circumstances

\begin{tabular}{clcc}
\hline \multirow{2}{*}{ No } & \multirow{2}{*}{ Circumstances } & \multicolumn{2}{c}{ Frequency } \\
\cline { 3 - 4 } & & ST & TT \\
\hline 1 & Location & 97 & 83 \\
2 & Manner & 25 & 13 \\
3 & Cause & 8 & 7 \\
4 & Accompaniment & 9 & 6 \\
5 & Extent & 5 & 2 \\
\hline & Total & $\mathbf{1 4 4}$ & $\mathbf{1 1 1}$ \\
\hline
\end{tabular}

Table 1 indicates that in the target text (TT), circumstances of location are reduced to 83 data, manner 13 data, cause 7 data, accompaniment 6 data, and circumstance of extent reduced to 2 data. The changes that appear in the Table 1 might have been caused by a number of possible causes including structural shift due to differences in the form of the two languages (Shahrokhi \& Lotfi, 2012). Because the specific objectives of this research are not to examine those changes, some few examples are provided for clarity. For instance in the two examples extracted from the Bible Society of South Africa (1971) chapter 12 verse 19 and 41:

\section{ST: "He will not wrangle or cry aloud," \\ TT: "Ia tidak akan bertengkar atau berteriak,"}

In the ST in chapter 12 verse 19 , the bolded part of a clause is a circumstance of manner - the quality explaining how the process (cry) will be actualized. However, in the $\mathrm{TT}$, the circumstances of manner that describes the quality of the process, change into the verbal, behavioral process to accommodate the meaning and the form of the target language.

ST: "The men of Nineveh will arise at the judgment with this generation and condemn it; for they repented at the preaching of Jonah, and behold, something greater than Jonah is here."
TT: "Pada Hari Kiamat, penduduk Niniwe akan bangkit bersama orang-orang zaman ini dan menuduh mereka. Sebab orang-orang Niniwe itu bertobat dari dosa-dosa mereka, ketika Yunus berkhotbah kepada mereka. Tetapi di sini sekarang ada yang lebih besar daripada Yunus!"

From the example in chapter 12 verse 41 , the bolded phrase in the source text (ST) shows the circumstance of location - time, but the translator in the target text (TT) changes it to a clause. Although the concept remains the same, the form of the ST changes from a phrase to a clause in the TT.

The translation techniques are analyzed from the target text as proposed by Molina and Albir (2002). From the componential analysis, the research indicates that the translator applies established equivalent, a combination of techniques (couplet) for example using established equivalent together with reduction techniques to translate a phrase structure, modulation, transposition, deletion, discursive creation, paraphrasing, implication, and explicitation with difference frequencies respectively. In the case of the combination of techniques, the translator applies two different techniques together to translate a certain structure that is in the form of a phrase in the source text. For instance, the combination of established equivalent together with generalization technique is applied in the following data Bible Society of South Africa (1971: 793).

ST: "For as Jonah was three days and three nights in the bell of the whale, so will the son of man be three days and three nights in the heart of the earth."

TT: "Yunus tinggal tiga hari tiga malam di dalam perut ikan besar. Begitu juga Anak Manusia akan tinggal tiga hari tiga malam di dalam perut bumi."

In the example in Bible Society of South Africa (1971: 793), the phrase in the TT "...ikan besar" is considered as the generalization of the source text phrase "...of the whale..." because a whale in its general sense is considered to be a big fish in the sea. Moreover, the research indicates that the use of the translation techniques is influenced by the form of the circumstance and not the type of the circumstance that is shown in Table 2.

Table 2 Distribution of Translation Techniques

\begin{tabular}{|c|c|c|c|c|c|c|c|c|c|c|}
\hline \multirow{2}{*}{$\underset{0}{0}$} & \multicolumn{9}{|c|}{ Translation Technique } & \multirow{2}{*}{$\frac{\vec{d}}{\stackrel{D}{0}}$} \\
\hline & 됟 & $\bar{\sigma}$ & $\Xi$ & 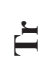 & $\overline{\mathrm{a}}$ & 소 & $\triangleq$ & 气̆ & 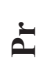 & \\
\hline 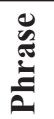 & 54 & 23 & 27 & 7 & 4 & - & 1 & 2 & 3 & 121 \\
\hline$\stackrel{\overrightarrow{0}}{0}$ & 15 & 2 & - & - & 2 & 2 & 1 & 1 & - & 23 \\
\hline है & 69 & 25 & 27 & 7 & 6 & 2 & 2 & 3 & 3 & 144 \\
\hline
\end{tabular}

From Table 2 of EE - Established Equivalence, Md - Modulation, Cm - Combination of techniques, $\mathrm{Tr}$ Transposition, Dl - Deletion, Ep - Explicitation, Ip - 
Implicitation, Dc - Discursive creation, Pr - Paraphrasing. 144 - indicate the total number of data studied.

It has been explained in the results in Table 2 that the application of the translation techniques is influenced by the form of the circumstances and not the type of the circumstances. Thus the discussion herein focuses on the pattern of the relationship between the translation technique in relation to its form and the quality of the translation. Molina and Albir (2002) suggest that translation techniques are procedures used by the translator to analyze and classify the equivalence or the closeness of the translation in relation to the source text. It, therefore, means that the aspect of translation quality intends to determine whether the target text accurately rendered the same message as that which is found in the source text, and to determine whether the target text conforms naturally to its cultural context in the aspect of acceptability (Nababan, Nuraeni, \& Sumardiono, 2012). The research reveals that the patterns of relationship are as seen in Table 3.

Table 3 Translation Techniques on Translation Quality

\begin{tabular}{|c|c|c|c|c|c|c|c|c|}
\hline \multirow{3}{*}{$\underset{\substack{0 \\
0}}{\Xi}$} & \multirow{3}{*}{ 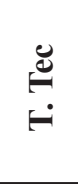 } & \multirow{3}{*}{ 冚 } & \multicolumn{6}{|c|}{ TQ } \\
\hline & & & \multicolumn{3}{|c|}{ Accuracy } & \multicolumn{3}{|c|}{ Acceptable } \\
\hline & & & 3 & 2 & 1 & 3 & 2 & 1 \\
\hline \multirow{6}{*}{$\frac{\overrightarrow{0}}{3}$} & $\mathrm{EE}$ & 15 & 15 & - & - & 15 & - & - \\
\hline & $\mathrm{Md}$ & 2 & 2 & - & - & 2 & - & - \\
\hline & Dl & 2 & - & - & 2 & - & - & 2 \\
\hline & Ep & 2 & - & 2 & - & 2 & - & - \\
\hline & Imp & 1 & 1 & - & - & 1 & - & - \\
\hline & Dc & 1 & - & - & 1 & 1 & - & - \\
\hline \multirow{8}{*}{$\frac{\mathscr{E}}{\mathbb{E}}$} & $\mathrm{EE}$ & 54 & 53 & 1 & - & 54 & - & - \\
\hline & Md & 23 & 5 & 18 & - & 23 & - & - \\
\hline & $\mathrm{Cm}$ & 27 & 22 & 5 & - & 27 & - & - \\
\hline & $\operatorname{Tr}$ & 7 & 1 & 6 & - & 7 & - & - \\
\hline & Dl & 4 & - & - & 4 & - & - & 4 \\
\hline & Ip & 1 & 1 & - & - & 1 & - & - \\
\hline & $\mathrm{Dc}$ & 2 & - & - & 2 & 1 & 1 & - \\
\hline & $\operatorname{Pr}$ & 3 & 1 & 2 & - & 3 & - & - \\
\hline Tot: & & 144 & 101 & 34 & 9 & 137 & 1 & 6 \\
\hline
\end{tabular}

From Table 3 EE - Established Equivalence, Md Modulation, $\mathrm{Cm}$ - Combination of techniques, $\mathrm{Tr}$ - Transposition, Dl - Deletion, Ip - Implicitation, Ep - Explicitation, Dc - Discursive creation, and $\mathrm{Pr}-$ Paraphrasing. T. Tec - Translation Techniques, and TQ Translation Quality.

3 - Accuracy, 2 - Less Accurate, and 1 - Not Accurate

3 -Acceptable, 2 - Less Acceptable, and 1 - Not Acceptable.

Table 2 and Table 3 indicate that the most applicable translation technique that the translator utilizes the most, in both word and phrase forms of the circumstantial elements is established equivalent. Table 2 indicates that a total of 69 data are translated using this technique (54 data in the form of phrases and 15 in the form of words). During the componential analysis, as the Table 3 indicates, the application of this technique resulted into a product which is accurate and acceptable in both forms - word and phrases, except in one case in which the product is rated less accurate, but acceptable. This claim is supported by Nababan, Nuraeni, and Sumardiono (2012), who claim that a translation is considered accurate when the meaning of words, technical terms, or phrases of the source language are accurately transferred into a target text.

The analysis as indicated by Table 3 shows that the meaning of words and phrases translated by the use of established equivalent technique are closely transferred into the target language. Established equivalent technique refers to the use of a term or an expression that is recognized as an equivalent of the source text in the target text (Molina \& Albir, 2002). In this context, an equivalent word or a phrase is used as long as it renders the same meaning as that which is found in the source text. For example in chapter 12 verse 2 and 40 .

ST: "Look, your disciples are doing what is not lawful to do on the sabbath."

TT: “Lihat! Pengikut-pengikut-Mu melanggar hukum agama kita dengan melakukan yang dilarang pada hari Sabat."

ST: "For as Jonah was three days and three nights in the belly of the whale, so will the Son of man be three days and three nights in the heart of the earth."

TT: "Yunus tinggal tiga hari tiga malam di dalam perut ikan besar. Begitu juga Anak Manusia akan tinggal tiga hari tiga malam di dalam perut bumi."

The example in chapter 12 verse 40 reveals that the bolded phrase in the former TT is the equivalence of the phrase in the ST. However, the phrase in latter TT "... di dalam perut bumi.", if literary translated will be meant "...in the stomach of the earth." But because the language at use recognizes it as the equivalent of the phrase "... in the heart of the earth" from the ST, it is accurate and hence acceptable. Unlike the research by Manggala (2017) that claims that material processes are used to show the obedience of the character in the Malaysian language, in this case, the circumstance of location-time is used to show that the event of doing unfolded on the Sabbath day, the day that Israelites are not allowed to do hard works but worship their God. And the latter shows where the character Jesus will be staying (the heart of the earth) for three days and three nights in comparison to Jonah, the Prophet.

Another translation technique that is highly deployed by the translator is the combination technique. In this context, it is revealed that a combination of two translation techniques such as established equivalent combined with explicitation (EE \& Ep) are used only to translate phrase structures. In most cases, this technique produces the translation that is accurate and acceptable except in five cases where the translation in the aspect of accuracy are less accurate but acceptable. In another word, the message in the target text in those five cases are less conforming to the source text message. For example, in chapter 12 verse 5 the author writes:

ST: "Or have you not read in the law how on the Sabbath the priests in the tample profane the sabbath, and are guiltless?"

TT: "Atau belum pernahkah kalian membaca di dalam hukum Musa bahwa tiap hari Sabat imamimam yang bertugas di Rumah Tuhan, melanggar peraturan hari Sabat, tetapi tidak disalahkan?" 
In chapter 12 verse 5 , the bolded phrase in the TT "...di dalam hukum Musa..." is a translation of the ST “... in the law..." which uses the combination of established equivalent and explicitation (reflected in "Musa") which is not formulated in the ST. In this context, the translator is clear to a reader that the law meant by the speaker is that which is written by Moses. This is because the mental behavioural process of reading is unfolded by the author taking place in the book of the law written by Moses. The translator provides clear information to the reader of the target text.

Furthermore, the modulation technique is another technique that the translator utilizes more. Unlike established equivalent, when modulation technique is deployed, tends to change the point of views, or focus of a cognitive category in relation to source text (Molina \& Albir, 2002). This means that in most cases where the technique is applied, the product in the aspect of accuracy is less accurate although acceptable. Table 3 reveals that in the form of words, the technique produces the translation which is accurate and acceptable except in the form of a phrase whereby only five data amongst 23 are accurate whilst 18 data are less accurate. However, all 23 data in the aspect of the acceptability are acceptable because the data naturally conform to the target language culture. For example, in chapter 13 verse 15 the author writes:

ST: "For this people's heart has grown dull, and their ears are heavy of hearing, and their eyes they have closed, lest they should perceive with their eyes,..."

TT: "Sebab pikiran orang-orang ini sudah menjadi tumpul, telinga mereka sudah menjadi tuli dan mata mereka jangan melihat,..."

From the example in chapter 13 verse 15 , in the ST clause, the phrase "...with their eyes,..." which is a circumstance of manner - as a means of perceiving, is changed into a senser (participant) of the mental process in the TT phrase "...mata mereka..." which reduces the quality of message intended in the ST by changing the means of actualizing a mental process into a participant of the process. Darani (2014) has claimed that mental processes are used to install the thoughts of leadership in the character's mind during the Napoleon era. This research reveals that the author applies the circumstance of means to unlock perception through the use of eyes, and when the translator deploys modulation technique changed the point of views of the source text structure as to conform to the target language structure. This concurs with Molina and Albir (2002) who claim that the technique when deployed tends to change the point of views or focus of a cognitive category of the source text. However, the correct translation is supposed to be "... sehingga mereka tidak melihat dengan mata mereka,..."

The research also reveals that transposition is deployed in the context where the circumstance is only in the form of phrases as Table 3 indicates. In the most context where this technique is deployed, the product is less accurate when seen from the aspect of accuracy, but all seven data are acceptable in the aspect of acceptability. The research further shows that there is only one instance in which the product is accurate. Again Molina and Albir (2002) claim that when this technique is applied tends to change a grammatical category of one language into another category of another language. This means that if for instance, a category in the source text is a circumstance, in the target text may either become a verb or adjective or undergo structural shift either from the initial position to any other location within the clause.

This is the reason why some of the circumstances that are translated using this technique transposition in terms of the class shift. Hence rated less accurate since the meaning in the target text when compared to that of the source text does not exactly conform to the source text's meaning. There is some distortion of the source text's meaning in the target text (Nababa, Nuraeni, \& Sumardiono, 2012). For example, in chapter 13 verse 30 the author writes:

ST: "Let both gow together until the harvest: and at harvest time I will tell the reapers, Gather the weeds first and bind them in bundles to be burned, but gather the wheat into my barn."

TT: "Biarkanlah alang-alang itu tumbuh bersamasama sampai waktu menuai. Nanti saya akan berkata kepada orang-orang yang menuai: Kumpulkan duluh alang-alangnya, ikat, lalu bakar. Sesudah itu kumpulkan gandummya, lalu simpan di dalam lumbung."

From the example in chapter 13 verse 30 , the ST phrase "...in bundles..." is the circumstance of manner (quality) describing the way in which the weeds will be tied. However, in the TT changes into a material process "...ikat...". Now, what is once a circumstance of manner describing the quality of how the process - material will be actualized in the ST becomes a process - material "...ikat..." in the TT which is acceptable in the TT because the target language lacks another structure that accommodates the phrase structure of the circumstance of quality formulated in the source language.

Apart from that, the research reveals more that the translator utilizes deletion technique in four instances where the circumstances are in the form of phrases and two instances in the form of words as Table 3 indicates. Molina and Albir (2002) refer to this technique as a reduction. The application of this technique suppresses the source text information or details in the target text resulting into inaccurate and unacceptable translation because the information in the source text is omitted or left out. As a result, the target text is reduced in meaning as it lacks some details or information that are formulated in the source text. For examples, at the beginning of chapter 12 verse 1, the author begins the story by saying:

ST: "At that time Jesus went through the grainfields on the sabbath; his disciples were hungry, and they began to pluck heads of grain and to eat."

TT: "Pada suatu hari Sabat, ketika Yesus lewat sebuah ladang gandum, pengikut-pengikut-Nya mulai memetik gandum, lalu memakananya karena lapar."

The example in chapter 12 verse 1 , the phrase "At that time..." which is formulated in the ST, is deleted or omitted in the TT. It is not reflected anywhere in the TT clause which makes it inaccurate and unacceptable. In this context, the translator is supposed to open the story with the phrase "Pada waktu itu,..." to accommodate the ST phrase "At that time...". Again in the same chapter verse 37, the author writes: 
ST: “...for by your words you will be justified, and by your words you will be condemned."

TT: "Sebab kata-katamu sendirilah yang akan dipakai untuk memutuskan apakah engakau bersalah atau tidak."

From the example in chapter 12 verse 37, the circumstance of manner - means "...by your words..." which is found in the ST, is deleted in the TT. What the translator does in the TT is to use the circumstance of cause - reason in the TT to reduce the information formulated in the ST. The translator is supposed to use the phrase "... dengan kata-katamu..." to accommodate the ST.

Furthermore, the research reveals that the translator deploys discursive creation technique. In the first instance, as Table 3 indicates, the translator applies the technique in the context where the circumstance is in the form of a word. In this context, the product in both aspects of the accuracy and acceptability of the translation quality is good. However, when the same technique is applied in the context where the circumstances ( 2 data) are in the form of phrases, the quality of the translation in the aspect of accuracy is inaccuracy, and in the aspect of acceptability, one data is acceptable and the second data is less acceptable. This is because the translator establishes a temporary equivalence which is completely unpredictable out of context (Molina \& Albir, 2002). For example, in chapter 13 verse 17 the author writes:

\section{ST: "Truly, I say to you,..." \\ TT: “Ingatlah,..."}

The example in chapter 13 verse 17 , the ST circumstance of manner - quality reflected in the structure "Truly" which describes the quality of what is going to be spoken, is translated into "Ingatlah" in the TT structure, which reflects the mental process of thinking. This translation is inaccuracy as it does not reflect on the quality of what is going to be spoken or told. The translator is supposed to translate it into "Benar-benar,..." to suit the ST meaning.

In addition, the research reveals that the translator also uses paraphrasing technique just in the context where the circumstances are in the form of phrases as Table 3 indicates. This is done by introducing or formulating new details that are not formulated in the source text (Molina \& Albir, 2002). By introducing new details in the translation, the translator aims at being clear to the reader of the target text. However, by doing so, the translation in two data amongst the three becomes less accurate, and only one data is accurate. In the case of the acceptability of the translation, all three data are acceptable. For instance, in chapter 12 verse 25 the author writes:

\section{ST: "Every kingdom divided against itself is laid waste,..."}

TT: "Kalau suatu negara terpecah dalam golongangolongan yang saling bermusuhan, negara itu tidak akan bertahan,..."

From the example in chapter 12 verse 25 , the bolded phrase "...against itself..." in the ST is the circumstance of cause describing the reason for the collapse of every kingdom. However, in the TT phrase, it is paraphrased into "...dalam golongan-golongan yang saling bermusuhan,..." by introducing a qualifier "...yang saling bermusuhan,...". In fact, the TT bolded phrase itself is a circumstance of location describing a place and not a reason for an event to occur. This technique reduces the intended message in the ST clause. This distorts the accuracy of the meaning found in the source text (Nababan, Nuraen, \& Sumardiono, 2012). The correct translation of that phrase will have been "... melawan dirinya sendiri..." to accommodate the message intended in the source text.

Lastly, the research reveals again that the translator uses the explicitation technique twice in the context where the circumstances are in the form of a word. The application of this technique resulted into a translation that is less accurate in both instances, but acceptable in the aspect of acceptability. Explicitation technique is used when a translator makes an item that may have been implicitly used in the source text clear in the target text by either using a common term or explicating by adding some details in the TT. Contrary to the explicitation technique, the translator uses implicitation technique which is the opposite of explicitation in the sense that the directly expressed item in the source text is condensed in the target text. This technique is applied once in each form of the circumstances and resulted into the translation which is accurate and acceptable. The two examples extracted from chapter 12 verse 19 and chapter 13 verse 45 illustrate:

\section{ST: "He will no wrangle or cry aloud, nor will any one} hear his voice in the streets;..."

TT: "Ia tidak akan bertengkar atau berteriak, atau berpidato di jalan-jalan raya."

In the ST example in chapter 12 verse 19, the word "...aloud,..." which indicates the quality in which the verbal behavioural process of crying will not be manipulated is implicitly translated as "...berteriak,..." (verbal behavioural process) in the TT. This translation renders the same message that is rendered in the source text because the process itself, in its TT culture, carries the quality of a shout or loudness. Hence the translation is accurate and acceptable. Nababan, Nuraeni, and Sumardiono (2012) support this argument when they claim that a translation is accurate and acceptable when the meaning of words and phrases are transferred accurately in the target language, and the translation sounds natural. This is what the researcher finds out. The meaning is transferred accurately, and the translation is natural in the target language.

\section{ST: “Again,..." \\ TT: “Apabila Allah memerintah, ..."}

The ST in chapter 13 verse 45, the word "Again,..." which refers to the circumstance of extent describing frequency or repetition, is explicated in the TT by the phrase structure "Apabila Allah memerintah,...". Although the translator explicates it by paraphrasing the source text word 'Again', this lowers the message intended in the source text because the precise translation that the translator will have used is supposed to be "Sekali lagi..." or "lagi,..." to conform to the source text message. In this context, the meaning of a source text word is distorted in the target text (Nababan, Nuraeni, \& Sumardiono, 2012).

\section{CONCLUSIONS}

From the translation analysis of circumstances discussed, it can be concluded that the deployment of translation techniques found in the target text is not 
influenced by the type of circumstances found in the source text, but is largely influenced by the form of the circumstances. Driven by the form, the translator has to determine the application of an appropriate technique that will result in a product that is accurate and acceptable. That is why in the context where the translator can hardly figure out the appropriate technique to be applied, ended up with a translation which is less accurate, and inaccurate in the aspect of accuracy. However, most of which are acceptable in the aspect of acceptability. There are few instances in which the translation is less and unacceptable.

The researchers suggest that since this research limits itself to the translation of circumstantial elements extracted from the Gospel According to Matthew Chapter 12, 13 and 14, in the New Testament (NT), further research can be conducted on the other chapters. It is not covered from the books of the Synoptic Gospels in the Holy Bible (Revised Standard Version) to find out more on what happens to the translation of circumstances within the source text, and that, this research be used as a motivating tool towards furthering the interpretation of the Holy Bible.

\section{REFERENCES}

Behnam, B., \& Zamanian, J. (2015). Genre analysis of Oxford and Tabriz applied linguistics research article abstracts: From move structure to transitivity analysis. The Journal of Applied Linguistics, 6(12), 41-59.

Beji, Y. (2016). Transitivity and context in critical discourse analysis case study: TAP headlines on regions in Tunisia. International Journal of Humanities and Cultural Studies, 2(4), 326-342. Retrieved from http://www.ijhcs.com/index.php/ijhcs/index.

Bible Society of South Africa. (1971). The holy bible: New testament $\left(2^{\text {nd }}\right.$ Ed.). South Africa: Bible Society of South Africa.

Chen, L. (2014). Experiential metafunctional analysis of Winston S. Churchill's speech on Hitler's invasion of the U.S.S.R. English Language Teaching, 7(9), 132-136. https://doi.org/10.5539/elt.v7n9p132.

Darani, L. H. (2014). Persuasive style and its realization through transitivity analysis: A SFL perspective. Procedia - Social and Behavioral Sciences, 158, 179186. https://doi.org/10.1016/j.sbspro.2014.12.066.

Halliday, M. A. K. (2014). Halliday's introduction to functional grammar (4 $4^{\text {th }} \mathrm{Ed}$.). London: Routledge. https://doi.org/10.4324/9780203431269.

House, J. (2015). Translation quality assessment: Past and present. London: Routledge.

Idrus, M. M., Nor, N. F. M., \& Ismail, I. S. (2014). Representing action: Transitivity and verb processes in Malaysian and Singaporean oral proceedings over Batu Puteh Island issue. Procedia - Social and Behavioral Sciences, 118(2), 180-183. https://doi. org/10.1016/j.sbspro.2014.02.024.

Kaffashi, M., Gowhary, H., Jamalinesari, A., \& Azizifar, A. (2015). A contrastive study of relational attributive clauses in narrative texts in English and Persian based on Halliday (2004). Procedia - Social and Behavioral Sciences, 192, 156-165. https://doi. org/10.1016/j.sbspro.2015.06.023.
Leech, G. N., \& Short, M. H. (2007). Style in fiction: A linguistic introduction to English fictional prose $\left(2^{\text {nd }}\right.$ Ed.). London: Routledge.

Manggala, S. A. (2017). The transitivity process patterns and styles in the characterization of the protagonist character in Phuoc's " the story of Tam and Cam." Journal of Language and Literature, 17(1), 65-73.

Molina, L., \& Albir, A. H. (2002). Translation techniques revisited: A dynamic and functionalist approach. Meta: Translators'Journal, 47(4), 498-512. Retrieved from http://id.erudit.org/iderudit/008033ar.

Nababan, M., Nuraeni, A., \& Sumardiono. (2012). Pengembangan model penilaian kualitas terjemahan. Kajian Linguistik dan Sastra, 24(1), 39-57.

Nguyen, H. T. (2012). Transitivity analysis of "Heroic Mother" by Hoa Pham. International Journal of English and Linguistics, 2(4), 85-100. https://doi. org/10.5539/ijel.v2n4p85.

Sabbachat, A., Mahdi, S., \& Sumantri, Y. S. (2014). Material process in transitivity of the English clauses: A functional grammar approach. International Journal of Language Learning and Applied Linguistics World (IJLLALW), 5(2), 70-79. Retrieved from ww.ijllalw. org.

Santosa, R. (2017). Metode penelitian kualitatif kebahasan. Surakarta: UNS Press.

Shahrokhi, M., \& Lotfi, R. A. (2012). Manifestation of transitivity parameters in Persian conversations: A comparative study. Procedia - Social and Behavioral Sciences, 46, 635-642. https://doi.org/10.1016/j. sbspro.2012.05.176.

Sun, Y., \& Zhao, Y. (2012). A comparison of transitivity system in English and Chinese. Cross-Cultural Communication, 8(4), 75-80. https://doi. org/10.3968/j.ccc.1923670020120804.2411.

Supatmiwati, D. (2013). Characters of William Shakespeare in translation on Shakespeare in love subtitling: A systemic functional linguistic approach. International Conference on Education and Language, Bandar Lampung, 2013. Bandar Lampung, Indonesia. pp. 143-156.

Wang, J. (2010). A critical discourse analysis of Barack Obama's speeches. Journal of Language Teaching and Research, 1(3), 254-261. https://doi.org/10.4304/ jltr.1.3.254-261.

Zahoor, M., \& Janjua, F. (2016). Character construction in tributive songs: Transitivity analysis of the song "I am Malala". Trames: A Journal of the Humanities and Social Sciences, 20(2), 201. https://doi. org/10.3176/tr.2016.2.05. 